\title{
Occurrence and Environmental Risks Assessment of DEET (N,N-diethyl-m-toluamide) Pesticide in Seyhan River, Turkey
}

\author{
Evşen YAVUZ GÜZEL \\ Cukurova University, Faculty of Fisheries, Department of Basic Sciences, Adana, Turkey
}

How to cite: Güzel, E.Y. (2021). Occurrence and Environmental Risks Assessment of DEET (N,N-diethyl-m-toluamide) Pesticide in Seyhan River, Turkey. J. Anatolian Env. and Anim. Sciences, 6(3), 345-351

Atıf yapmak için: Güzel, E.Y. (2021). Seyhan Nehri'nde DEET (N, N-dietil-m-toluamid) Pestisitinin Bulunurluğu ve Çevresel Risk Değerlendirmesi. Anadolu Çev. ve Hay. Dergisi, 6(3), 345-351.

\section{* [D : https://orcid.org/0000-0002-8029-9254}

\section{*Corresponding author's:}

Evsen YAVUZ GÜZEL

Cukurova University, Faculty of Fisheries,

Department of Basic Sciences, Adana, Turkey

$\bowtie$ : eguzel@cu.edu.tr

\begin{abstract}
The insect repellent DEET ( $N, N$-diethyl- $m$-toluamide) is one of the most common organic chemical pollutants in water in a wide range of countries around the World. In this study, surface water samples were collected seasonally, from 7 stations in Seyhan River, following a period between December 2016 and November 2017. The DEET concentrations in Seyhan River were detected between 18.55-334.71 ng/L. DEET was detected in all seven sampling stations and detection frequency was $100 \%$. Results obtained in autumn were higher than in summer. According to the environmental risk assessment, DEET in the Seyhan River, has no environmental risk (all measured RQ values were lower than 0.01).
\end{abstract}

Keywords: Environmental risk assessment, insect repellent, pesticide, seyhan river, water pollution.

\section{Seyhan Nehri'nde DEET (N, N-dietil-m-toluamid) Pestisitinin Bulunurluğu ve Çevresel Risk Değerlendirmesi}

\section{*Sorumlu yazar:}

Evsen YAVUZ GÜZEL

Çukurova Üniversitesi, Su Ürünleri Fakültesi,

Temel Bilimler Bölümü, Adana, Türkiye

凶: eguzel@cu.edu.tr
Öz: Böcek kovucu DEET, dünyadaki çok çeşitli ülkelerde suda bulunan en yaygın organik kimyasal kirleticilerden biridir. Bu çalışmada, Aralık 2016 ile Kasım 2017 tarihleri arasında, Seyhan Nehri'ndeki 7 istasyondan mevsimsel olarak yüzey suyu örnekleri toplanmıştır. Seyhan Nehri'ndeki DEET konsantrasyonları 18,55-334,71 ng/L arasında tespit edilmiştir. Yedi örnekleme istasyonunun tamamında DEET tespit edilmiş olup, tespit frekansı \% 100'dür. Sonbaharda elde edilen sonuçlar yaz aylarına göre daha yüksek bulunmuştur. Çevresel risk değerlendirmesine göre Seyhan Nehri'ndeki DEET'in çevresel riski yoktur (ölçülen tüm RQ değerleri 0,01'den düşük bulunmuştur).

Anahtar kelimeler: Cevresel risk değerlendirmesi, böcek kovucu, pestisit, Seyhan Nehri, su kirliliği.

\section{INTRODUCTION}

Personal care products (PCPs) are compounds used in lotions, toothpastes, soaps, fragrances and sunscreen products. The classes of PCPs include insect repellents, preservatives, disinfectants, fragrances, and UV filters. PCPs are products for external use on the human body and are therefore not subject to metabolic changes. Consequently, large amounts of PCPs enter the environment through regular use (Brausch \& Rand, 2011). PCPs are considered as environmental emerging pollutants due to their sustained release into the aquatic environment 
and the persistence of ecotoxicological impacts (Calza, Medana, Raso, Giancotti, \& Minero, 2011).

Insect repellents are organic synthetic chemicals that can be applied on garments, skin or other surfaces to prevent the effects of insects and insect bites. Mosquito, fly, fleas and spiders are the most common insect bites. Bites can produce many side effects such as skin irritation, allergic reactions, infections, fever or encephalitis. And even western Nile fever, malaria, dang can cause diseases such as spread (Molins-Delgado, García-Sillero, DíazCruz, \& Barceló, 2018). DEET (N,N-diethyl-m-toluamide or N,N-diethyl-3-methylbenzamide) is the most widely used insect repellent for the prevention of bites from insects (Calza et al., 2011; Guzel, Cevik, \& Daglioglu, 2017).

DEET was developed in 1946 by the US military to protect against mosquito bites related diseases during World War II. In 1957, DEET was made available for public use. EPA has declared this product safe for normal use. However, there is still a debate on whether DEET constitutes a significant risk for people, animals and the environment (Campos et al., 2016; Merel, Nikiforov, \& Snyder, 2015).

DEET is sold in a wide variety of products including lotions, sprays, and wristbands. The formulations used can vary from $4 \%$ to $95 \%$ of the active ingredient. Agricultural use of DEET has also been reported (Aronson, Weeks, Meylan, Guiney, \& Howard, 2012). As of 2017, 27 companies in the United States reported that about 119 consumer products containing DEET were in use (Keith et al., 2017). However, such data could not be found for Turkey.

The presence of DEET in the aqueous environment contains many and potentially complex pathways. DEET can be released directly or indirectly to the environment by its presence in commercial products. There is no known natural source of DEET known to be environmentally important. Due to recreational activities such as swimming (via skin or clothing of swimmers or indirectly over spraying), DEET can directly enter surface waters. Although often neglected, domestic waters (through human activities such as showering and bathing) are now expected to be the major source of DEET in the aquatic environment (Keith et al., 2017; Merel \& Snyder, 2016). These aquatic environments being often used as drinking or tap water sources. So DEET can be detected in water for human consumption (Merel et al., 2015; Merel \& Snyder, 2016).

The insect repellent DEET is one of the most common organic chemical pollutants in water in a wide range of countries from all around the world (Merel \& Snyder, 2016).
The first studies about the occurrence of DEET in the aquatic environment was in samples of Swedish municipal landfill leachate and in Mississippi river (USA) were published in 1993 (Öman \& Hynning, 1993; Pereira \& Hostettler, 1993). DEET has been identified and quantified in different aquatic environments, such as surface water (Bartelt-Hunt, Snow, Damon, Shockley, \& Hoagland, 2009; Calza et al., 2011; Costanzo, Watkinson, Murby, Kolpin, \& Sandstrom, 2007; Guzel, Cevik, \& Daglioglu, 2018b; Ma et al., 2016; Yoon, Ryu, Oh, Choi, \& Snyder, 2010), ground water (Sorensen et al., 2015; Stuart, Lapworth, Crane, \& Hart, 2012), drinking water (Benotti et al., 2009), seawater (Dsikowitzky et al., 2014) and wastewater treatment plants (Bartelt-Hunt et al., 2009; Costanzo et al., 2007; Glassmeyer et al., 2005). Studies on the presence of DEET in surface waters have increased significantly since 2000. The reason for this is that the sensitivity of the analytical methods used to detect DEET has increased over the last two decades (Aronson et al., 2012). With the present methodology, DEET can detect even at concentrations of $<0.1 \mathrm{ng} / \mathrm{L}$. European studies about the occurrence of DEET are limited to Western countries. And Asian studies are mostly dominated by China but highest DEET concentrations were also reported for Indonesia (Dsikowitzky et al., 2014; Merel \& Snyder, 2016).

Numerous reviews and researches have been published investigating toxicity (Legeay, Clere, ApaireMarchais, Faure, \& Lapied, 2018; Martinez, Vélez, Mayo, \& Sastre, 2016; Swale, Sun, Tong, \& Bloomquist, 2014; Weeks, Guiney, \& Nikiforovz, 2012) and occurrence of DEET in aquatic environments (Bartelt-Hunt et al., 2009; Benotti et al., 2009; Guzel et al., 2018b; Sandstrom, Kolpin, Thurman, \& Zaugg, 2005). But less attention has been paid to identify the environmental risk assessment of PCPs especially insect repellents release on aquatic environments (Aronson et al., 2012; Sun et al., 2016).

In the Seyhan River Basin, there are freshwater marshes, salt marshes and reed marshes suitable for proleferiation of mosquito species (TUBITAK MAM, n.d.). Although the municipalities in the basin apply pesticides to combat mosquitoes, mosquito populations can be quite intense in some areas close to wetlands.

The present study aims to investigate the occurrence of DEET pesticide in Seyhan River surface water samples for assessing seasonal and spatial variations (seasonal sampling over one year) in seven stations. And the other aim of this study is to calculate the risk quotient (RQ) with the measured concentrations of DEET obtained from Seyhan River and to determine the environmental risks. To our knowledge this is the first study about the occurrence and environmental risk assessment of DEET in Seyhan River, Turkey. 


\section{MATERIALS AND METHODS}

Chemicals and materials: Methanol (MeOH), methyl tert-butyl ether (MTBE) and water were gradient grade for liquid chromatography and purchased from Merck Millipore, Germany. Solid-phase extraction (SPE) cartridges (Oasis HLB, $500 \mathrm{mg}, 6 \mathrm{~cm} 3$ ), SPE extraction manifold (20-positions) which combined with vacuum pomp were purchased from Waters (Millford, MA, USA). DEET (<98\%) was purchased from Sigma-Aldrich (Steinheim, Germany). Internal standard diazepam-d5 (99\%) was obtained from Lipomed (Switzerland). Glass fibre filter disks (GF/C, pore size $1.2 \mu \mathrm{m}$ ) were purchased from Whatmann (VWR, Belgium). Allure ${ }^{\circledR}$ Pentafluorophenylpropyl (PFPP) column (50 mm x 2.1 $\mathrm{mm}, 5 \mu \mathrm{m}$ ) was purchased from Restek (Bellefonte, PA, $\mathrm{ABD})$.

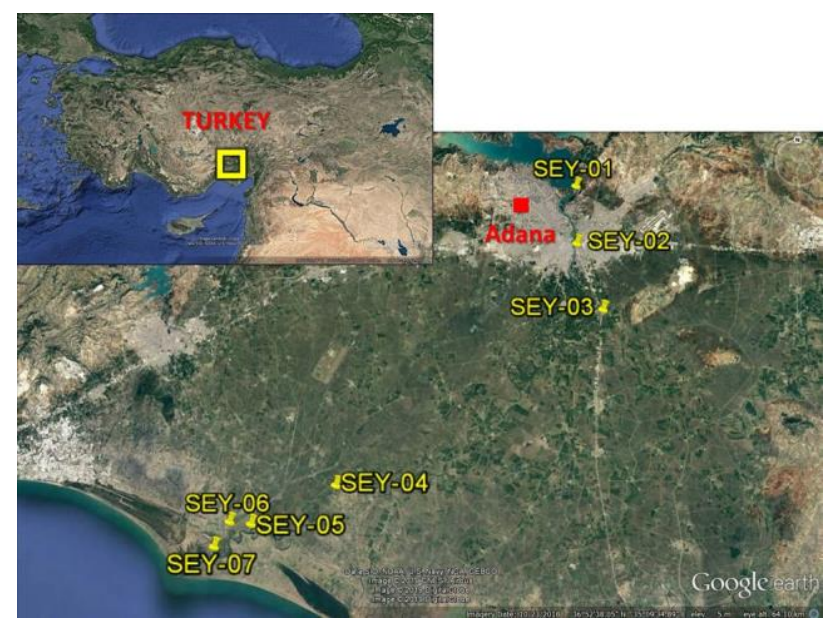

Figure 1. Geographic location of Seyhan River in Turkey and sampling stations.

Sampling site and sample collection: The Seyhan River is the longest river in Turkey that flows into the Mediterranean Sea. It is located in the Seyhan Basin, south Turkey, and this basin has the total drainage area of 20.600 $\mathrm{km}^{2}$. The total length of the Seyhan River is approximately $560 \mathrm{~km}$. According to population and area information, population density is 83 person $/ \mathrm{km}^{2}$. Surface water samples were collected seasonally, from 7 stations in Seyhan River, following a period between December 2016 and November 2017. First two stations (SEY-01 $\left(37^{\circ}\right.$ $\left.1^{\prime} 59.94 " \mathrm{~N}, 35^{\circ} 20^{\prime} 29.66^{\prime \prime} \mathrm{E}\right)$ and SEY-02 (36 58'45.92"N, $35^{\circ} 20^{\prime} 5.90^{\prime \prime} \mathrm{E}$ ) are dominated by a large city centre (Adana) where 1.7 million inhabitants living. SEY-03 $\left(36^{\circ} 55^{\prime} 6.59^{\prime \prime} \mathrm{N}, 35^{\circ} 21^{\prime} 16.66^{\prime \prime E}\right)$, SEY-04 (36 $47^{\prime} 4.66^{\prime \prime} \mathrm{N}$, $\left.35^{\circ} \quad 3^{\prime} 47.58^{\prime \prime} \mathrm{E}\right)$, and SEY-06 $\left(36^{\circ} 45^{\prime} 39.10^{\prime \prime} \mathrm{N}\right.$, $\left.34^{\circ} 57^{\prime} 20.16^{\prime \prime} \mathrm{E}\right)$ surrounded by a variety of land uses including agriculture and industry. SEY-05 $\left(36^{\circ} 45^{\prime} 29.03^{\prime \prime} \mathrm{N}, 3^{\circ} 58^{\prime} 36.87^{\prime \prime} \mathrm{E}\right)$ is located on a drainage canal near Baharli Village that carries waste water. SEY07 is located in the region where Seyhan River and drainage channel are mixed and poured into the Mediterranean Sea. Surface waters were sampled from a depth of approximately $25 \mathrm{~cm}$. Water samples were transferred in a cooler bag to the laboratory. In the autumn season sampling, no sample was taken at SEY-03 station, as there was no water.

Sample preparation and extraction: Water samples were filtered through glass fibre filters $(\mathrm{GF} / \mathrm{C})$ and $\mathrm{H}_{2} \mathrm{SO}_{4}$ was added for $\mathrm{pH}$ adjustment $(\mathrm{pH}=2 \pm 0.1)$. Solid phase extraction (SPE) was used for sample preparation before instrumental analysis. $1 \mathrm{~L}$ filtered surface water samples were loaded through preconditioned (Oasis HLB cartridges) SPE cartridges at a flow rate of $15 \mathrm{~mL} / \mathrm{min}$ using a vacuum extraction manifold (Waters 20-Position extraction manifold (Milford, MA, USA)).

Instrumental analysis: Chromatographic analyses were carried out with ultra-fast liquid chromatography (Shimadzu CBM-20A), automatic sampling system (Shimadzu SIL-20A/HT) and mass spectrometry (Shimadzu 8030, Kyoto, Japan). DEET was separated chromatographically on PFPP column $\left(\right.$ at $40{ }^{\circ} \mathrm{C}$, flow rate of $0.4 \mathrm{~mL} / \mathrm{min}$ ) using ultra-pure water with 10 $\mathrm{mM}$ ammonium formate (eluent A) and methanol (eluent B), with the gradient program started with $10 \%$ eluent $\mathrm{B}$ and was held for $10 \mathrm{~min}$ at a flow rate of $0.4 \mathrm{~mL} / \mathrm{min}$. Multiple reactions monitoring (MRM) mode was used for the determination of DEET (precursor: 192.2, products 91.1 and 119.1). Total method run time was 18 minutes. The retention time was 7.78 minute. The area ratio of the ions and retention time were compared by using the standard solutions under identical conditions. The limit of quantification (LOQ) was 0.3 and the limit of detection (LOD) was $0.2 \mathrm{ng} / \mathrm{L}$ for the DEET method. The correlation coefficients for calibration curve was higher than 0.99 .

Environmental risk assessment calculations: Risk quotient (RQ) was calculated for the environmental risk assessment. The hazard and environmental risk level of DEET compound in the receiving environment can be determined by calculating the RQ value. PNEC value is calculated by using the smallest NOEC value calculated for many different species in ecotoxicology studies and the assessment factor (AF) suitable for the recipient environment (Aronson et al., 2012; Guzel, Cevik, \& Daglioglu, 2018a). RQ formula is:

\section{$R Q=M E C / P N E C$}

In this formula, MEC is the measured environmental concentrations and PNEC is the no effect concentration in the surface water. If RQ values; $<0.1$ means insignificant risk (no adverse effect expected), = 0.1-1 means low risk (potential adverse effects), $=1-10$ means moderate risk (probable adverse effect) and > 10 means high risk (Ma et al., 2016). The PNEC value for DEET is 47000 (ECOSAR (Ecological Structure Activity 
Relationship) class program Version 1.11 was used to obtain the pNEC value).

\section{RESULTS}

DEET was detected in all sampling stations, concentrations in Seyhan River were between $18.55 \mathrm{ng} / \mathrm{L}$ and $334.71 \mathrm{ng} / \mathrm{L}$ and detection frequency was $100 \%$. Mean, median, maximum and minimum concentrations were listed in Table 1.

The lowest DEET concentration was found as $18.55 \mathrm{ng} / \mathrm{L}$ in winter and highest concentration was found as $334.71 \mathrm{ng} / \mathrm{L}$ in autumn. The mean concentrations of DEET were found as 32.58, 78.31, 81.46 and $171.66 \mathrm{ng} / \mathrm{L}$ in winter, spring, summer and autumn respectively (Fig.2).

Table 1. DEET concentrations in surface waters of Turkey and other countries.

\begin{tabular}{|c|c|c|c|c|c|}
\hline Study Area & $\begin{array}{l}\text { Mean } \\
(\mathrm{ng} / \mathrm{L})\end{array}$ & $\begin{array}{c}\text { Median } \\
(\mathrm{ng} / \mathrm{L})\end{array}$ & $\begin{array}{c}\text { Min. } \\
\text { (ng/L) }\end{array}$ & $\begin{array}{l}\text { Max. } \\
(\mathrm{ng} / \mathrm{L})\end{array}$ & References \\
\hline Seyhan River, Turkey & 88.01 & 75.89 & 18.55 & 334.71 & *This study \\
\hline Ceyhan River, Turkey & 12.45 & 4.41 & 0.57 & 40.41 & (Guzel et al., 2018b) \\
\hline Konya Basin Lakes, Turkey & 3.92 & 3.57 & 3.41 & 4.79 & (Guzel et al., 2018b) \\
\hline Antalya Basin Lakes, Turkey & 3.43 & 2.73 & 1.54 & 7.77 & (Guzel et al., 2018b) \\
\hline Ceyhan Basin Lakes, Turkey & 3.45 & 2.56 & 0.64 & 14.22 & (Guzel et al., 2018b) \\
\hline Seyhan Dam Lake, Turkey & 5.50 & 1.78 & 1.01 & 17.43 & (Guzel et al., 2018b) \\
\hline USA & - & 55 & 13 & 660 & (Brausch \& Rand, 2011) \\
\hline The Northern River, Germany & - & - & 0.11 & 1.09 & (Weigel et al., 2002) \\
\hline Po River, Italy & - & - & 0.6 & 155.55 & (Calza et al., 2011) \\
\hline $\begin{array}{l}\text { Schwarzbach, Modau, Winkelbach, and } \\
\text { Weschnitz Rivers, Germany }\end{array}$ & 124 & - & $<\mathrm{LOD}$ & 1292 & (Quednow \& Püttmann, 2009) \\
\hline Zhujiang, Shijing Rivers, China & - & - & 0.2 & 107 & (Yang et al., 2013) \\
\hline Jakarda River, Indonesia & - & - & 30 & 24000 & (Dsikowitzky et al., 2014) \\
\hline Han River, South Korea & 160 & 190 & 120 & - & (Yoon et al., 2010) \\
\hline 5 stream sites, USA & - & - & 30 & 180 & (Mottaleb, Usenko, Brooks, \& Chambliss, 2009) \\
\hline Assunpink Creek, USA & - & - & 45 & 340 & (Alvarez et al., 2005) \\
\hline 139 stream sites, USA & - & 60 & - & 1100 & (Kolpin et al., 2002) \\
\hline
\end{tabular}

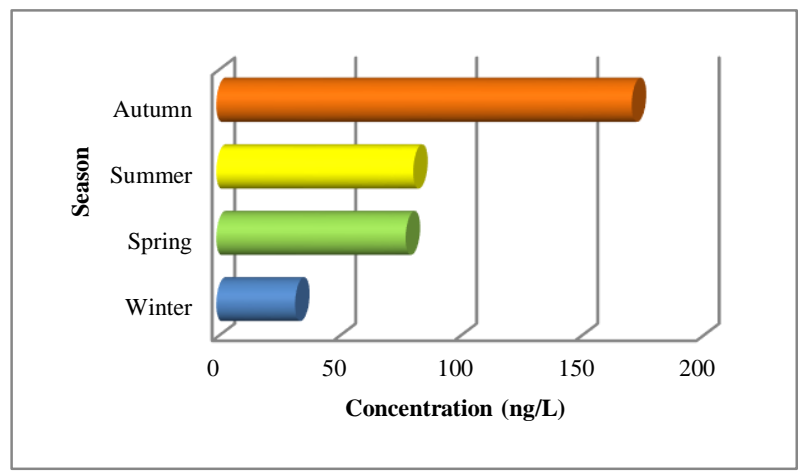

Figure. 2. Seasonal comparison of DEET concentrations (ng/L) in Seyhan River

In Figure 3, the cumulative distribution of DEET concentrations measured in Seyhan River by stations was shown. DEET detected higher where there was the possibility of wastewater contamination, via human, industrial, and agricultural sources, entering the streams and near urban areas during summer and late winter (autumn). The station where the highest DEET concentration measured was SEY-06 was under the influence of the influent wastewaters of Seyhan wastewater treatment plant (WWTP), which is the largest WWTP in Adana Province, and during the field studies, it was observed that the mosquito population around the station was very high in autumn. Recent studies indicate that the highest DEET concentration in aquatic environments correlates with its increased application during the summer months and late winter (Keith et al., 2017; Merel et al., 2015; Sandstrom et al., 2005).

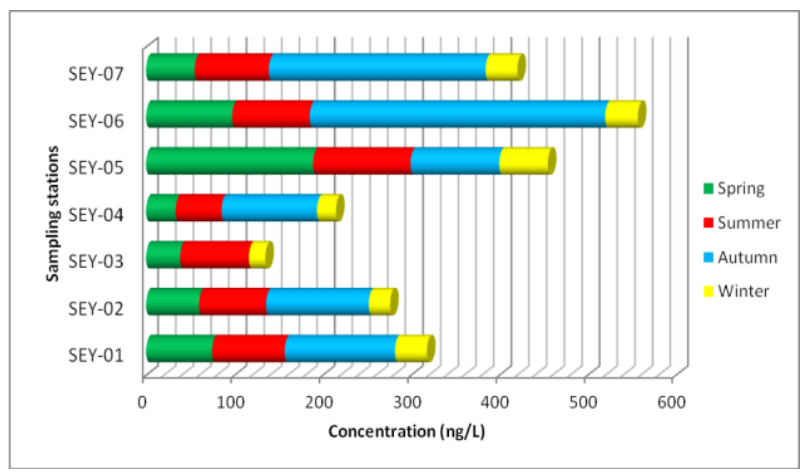

Figure 3. Cumulative and spatial comparison of DEET concentrations (ng/L) in Seyhan River

A study which was a summary of latest studies in surface water samples published in 2011 reported concentrations ranging from 13 to $660 \mathrm{ng} / \mathrm{L}$ for DEET throughout the USA (Brausch \& Rand, 2011). In another review which reported worldwide DEET concentrations in water samples ranging from 40-3000 ng/L (Costanzo et al., 2007). Along the northern River, Germany DEET concentrations was between 0.11 to $1.09 \mathrm{ng} / \mathrm{L}$ (Weigel, Kuhlmann, \& Huhnerfuss, 2002).DEET concentrations in Po River water samples were between 0.6 to $155.55 \mathrm{ng} / \mathrm{L}$ (Calza et al., 2011). Water samples taken from the Zhujiang and Shijing Rivers, concentrations of DEET were minimum $0.2 \mathrm{ng} / \mathrm{L}$ and maximum $107 \mathrm{ng} / \mathrm{L}$. And in Assunpink Creek in Trenton, New Jersey DEET was detected at levels of 45-340 ng/L (Alvarez et al., 2005). DEET was detected in $74.1 \%$ of the water samples analyzed at a maximum concentration of $1100 \mathrm{ng} / \mathrm{L}$ (Kolpin et al., 2002). In Table 1, DEET concentrations in 
Seyhan River compared with Ceyhan River (Turkey), Konya Basin Lakes (Turkey), Antalya Basin Lakes (Turkey), Ceyhan Basin Lakes (Turkey), Seyhan Dam Lake (Turkey), The Northern River (Germany), Po River (Italy), Schwarzbach, Modau, Winkelbach, and Weschnitz Rivers (Germany), Zhujiang and Shijing Rivers (China), Jakarda River (Indonesia), Han River (South Korea), 5 stream sites, Assunpink Creek and 139 stream sites (USA). Highest DEET concentrations in Turkey were detected for Seyhan River. Among the studies in the world, the highest DEET concentration was measured in Jakarda River, Indonesia (max: 24000 ng/L) (Dsikowitzky et al., 2014), followed by the results of Winkelbach, and Weschnitz Rivers (1292 ng/L) in Germany (Quednow \& Püttmann, 2009), and the results of 139 stream waters (1100 ng/L) in the United States (Kolpin et al., 2002).
Risk assessment calculations were made for each station and season using DEET concentrations measured in the Seyhan River. According to the environmental risk assessment, DEET in the Seyhan River, pose no environmental risk (all measured RQ values were lower than 0.01, means no environmental risk) (Table 2). However, toxic effects may be higher when all pollutants behave together in natural environment.

As a result, DEET pesticide has been detected in all surface waters collected seasonally over a year from the Seyhan River, with concentrations varying between 18.55$334.71 \mathrm{ng} / \mathrm{L}$. Aquatic organisms are thought to be affected as result of chronic exposure to DEET. The results obtained for Seyhan River were found lower than in USA (4700 ng $\mathrm{L}^{-1}$ in surface waters) and Europe. According to the risk assessment calculations, it was determined that the current concentrations of DEET pesticide do not pose an environmental risk.

Table 2. Measured environmental concentrations (MECs) and risk quotient values (RQs) of DEET detected in Seyhan River.

\begin{tabular}{|c|c|c|c|c|c|c|c|c|}
\hline & \multicolumn{4}{|c|}{ MECs (ng/L) } & \multicolumn{4}{|c|}{ RQs } \\
\hline & Spring & Summer & Autumn & Winter & Spring & Summer & Autumn & Winter \\
\hline SEY-01 & 74.749 & 82.096 & 124.964 & 36.125 & 0.002 & 0.002 & 0.003 & 0.001 \\
\hline SEY-02 & 59.99 & 75.886 & 116.257 & 24.185 & 0.001 & 0.002 & 0.002 & 0.001 \\
\hline SEY-04 & 33.388 & 52.065 & 108.089 & 21.457 & 0.001 & 0.001 & 0.002 & 0.000 \\
\hline SEY-05 & 189.121 & 110.308 & 100.505 & 54.985 & 0.004 & 0.002 & 0.002 & 0.001 \\
\hline SEY-06 & 97.414 & 87.849 & 334.713 & 36.898 & 0.002 & 0.002 & 0.007 & 0.001 \\
\hline SEY-07 & 54.985 & 84.047 & 245.442 & 35.894 & 0.001 & 0.002 & 0.005 & 0.001 \\
\hline
\end{tabular}

\section{CONCLUSION}

This study was one of the first and most comprehensive studies in the region. The results obtained in autumn were found higher than in summer. It was unexpected, but it provides clue about the season that mosquitos are found more. The results obtained for Seyhan River were found lower than in USA and Europe. In future studies, bioaccumulation of DEET should be added to such research. Because DEET can accumulate in aquatic organisms and damage as a result of continuous exposure.

\section{REFERENCES}

Alvarez, D. A., Stackelberg, P. E., Petty, J. D., Huckins, J. N., Furlong, E. T., Zaugg, S. D. \& Meyer, M. T. (2005). Comparison of a novel passive sampler to standard water-column sampling for organic contaminants associated with wastewater effluents entering a New Jersey stream. Chemosphere, 61(5), 610-622. DOI: 10.1016/j.chemosphere.2005.03.023

Aronson, D., Weeks, J. Meylan, B., Guiney, P. D., \& Howard, P. H. (2012). Environmental release, environmental concentrations, and ecological risk of N,N-diethyl-m-toluamide (DEET). Integrated Environmental Assessment and Management, 8(1), 135-166. DOI: 10.1002/ieam.271
Bartelt-Hunt, S. L., Snow, D. D., Damon, T., Shockley, J. \& Hoagland, K. (2009). The occurrence of illicit and therapeutic pharmaceuticals in wastewater effluent and surface waters in Nebraska. Environmental Pollution, 157(3), 786791.

https://doi.org/10.1016/j.envpol.2008.11.025

Benotti, M. J., Trenholm, R. A., Vanderford, B. J., Holady, J. C., Stanford, B. D. \& Snyder, S. A. (2009). Pharmaceuticals and endocrine disrupting compounds in U.S. drinking water. Environmental Science and Technology, 43(3), 597-603. DOI: 10.1021/es801845a

Brausch, J. M. \& Rand, G. M. (2011). A review of personal care products in the aquatic environment: Environmental concentrations and toxicity. Chemosphere, 82(11), 1518-1532. DOI: 10.1016/j.chemosphere.2010.11.018

Calza, P., Medana, C., Raso, E., Giancotti, V. \& Minero, C. (2011). N,N-diethyl-m-toluamide transformation in river water. Science of the Total Environment, 409(19), 3894-3901. DOI: 10.1016/j.scitotenv.2011.06.006

Campos, D., Gravato, C., Quintaneiro, C., Koba, O., Randak, T., Soares, A. M. V. M. \& Pestana, J. L. T. (2016). Are insect repellents toxic to freshwater insects? A case study using caddisflies exposed to DEET. Chemosphere, 149, 177-182. DOI: 10.1016/j.chemosphere.2016.01.098 
Costanzo, S. D., Watkinson, A. J., Murby, E. J., Kolpin, D. W. \& Sandstrom, M. W. (2007). Is there a risk associated with the insect repellent DEET (N,N-diethyl-m-toluamide) commonly found in aquatic environments? Science of the Total Environment, 384(1-3), 214-220. DOI: 10.1016/j.scitotenv.2007.05.036

Dsikowitzky, L., Dwiyitno, Heruwati, E., Ariyani, F., Irianto, H. E. \& Schwarzbauer, J. (2014). Exceptionally high concentrations of the insect repellent $\mathrm{N}, \mathrm{N}$-diethyl-m-toluamide (DEET) in surface waters from Jakarta, Indonesia. Environmental Chemistry Letters, 12(3), 407-411. DOI: 10.1007/s10311-014-0462-6

Glassmeyer, S. T., Furlong, E. T., Kolpin, D. W., Cahill, J. D., Zaugg, S. D., Werner, S. L. \&Kryak, D. D. (2005). Transport of chemical and microbial compounds from known wastewater discharges: Potential for use as indicators of human fecal contamination. Environmental Science and Technology, 39(14), 5157-5169. DOI: 10.1021/es048120k

Guzel, E. Y., Cevik, F. \& Daglioglu, N. (2017). DEET (N,N-diethyl-m-toluamide) pestisitinin Orta Güney Türkiye yüzey sularında bulunurluğu ve mevsimsel değişimi. In 2nd International waer and Health Congress (p. 390). Antalya, Turkey.

Guzel, E. Y., Cevik, F. \& Daglioglu, N. (2018a). Determination of pharmaceutical active compounds in Ceyhan River, Turkey: Seasonal, spatial variations and environmental risk assessment. Human and Ecological Risk Assessment: An International Journal, 25(8), 1980-1995.

DOI: 10.1080/10807039.2018.1479631

Guzel, E. Y., Cevik, F. \& Daglioglu, N. (2018b). Occurrence and seasonal changes of N,N-diethyl$\mathrm{m}$-toluamide ( DEET ) pesticide in Middle South Turkey surface waters. Journal of Environmental Protection and Ecology, 987(3), 978-987.

Keith, S., Harper, C., Ashizawa, A., Williams, R., Llados, F., Coley, C. \& Carlson-Lynch, H. (2017). Toxicological Profile for DEET (N,NDiethyl-meta-toluamide). U.S. Department of Health and Human Services-Agency for Toxic Substances and Disease Registry. Atlanta, Georgia, USA. DOI: 10.1155/2013/286524

Kolpin, D. W., Furlong, E. T., Meyer, M. T., Thurman, E. M., Zaugg, S. D., Barber, L. B. \& Buxton, H. T. (2002). Pharmaceuticals , Hormones, and Other Organic Wastewater Contaminants in U.S. Streams, 1999-2000 : A National Reconnaissance. Environmental Science \& Technology, 36(6), 1202-1211. DOI: 10.1021/es011055j

Legeay, S., Clere, N., Apaire-Marchais, V., Faure, S. \& Lapied, B. (2018). Unusual modes of action of the repellent DEET in insects highlight some human side effects. European Journal of Pharmacology, 825(September 2017), 92-98. DOI: 10.1016/j.ejphar.2018.02.033

Ma, R., Wang, B., Lu, S., Zhang, Y., Yin, L., Huang, J.,
Deng, S., Wang, Y. \& Yu, G. (2016). Characterization of pharmaceutically active compounds in Dongting Lake, China: Occurrence, chiral profiling and environmental risk. Science of the Total Environment, 557-558, 268-275. DOI: 10.1016/j.scitotenv.2016.03.053

Martinez, E., Vélez, S. M., Mayo, M. \& Sastre, M. P. (2016). Acute toxicity assessment of N,N-diethyl$\mathrm{m}$-toluamide (DEET) on the oxygen flux of the dinoflagellate Gymnodinium instriatum. Ecotoxicology, 25(1), 248-252. DOI: Ö10.1007/s10646-015-1564-Z

Merel, S., Nikiforov, A. I. \& Snyder, S. A. (2015). Potential analytical interferences and seasonal variability in diethyltoluamide environmental monitoring programs. Chemosphere, 127, 238245. DOI: 10.1016/j.chemosphere.2015.02.025

Merel, S. \& Snyder, S. A. (2016). Critical assessment of the ubiquitous occurrence and fate of the insect repellent $\mathrm{N}, \mathrm{N}$-diethyl-m-toluamide in water. Environment International, 96, 98-117. DOI: 10.1016/j.envint.2016.09.004

Molins-Delgado, D., García-Sillero, D., Díaz-Cruz, M. S. \& Barceló, D. (2018). On-line solid phase extraction-liquid chromatography-tandem mass spectrometry for insect repellent residue analysis in surface waters using atmospheric pressure photoionization. Journal of Chromatography A, 1544, 33-40. DOI: 10.1016/j.chroma.2018.02.027

Mottaleb, M. A., Usenko, S., Brooks, B. W. \& Chambliss, C. K. (2009). Simultaneous analysis of different classes of personal care products in river water by a single gas chromatographytandem mass spectrometry method. Environmental Pollution, 30(March 2009), 1-9. DOI: 10.1016/j.envpol.2009.02.008

Öman, C. \& Hynning, P.-Å. (1993). Identification of organic compounds in municipal landfill leachates. Environmental Pollution, 80(3), 265271. DOI: 10.1016/0269-7491(93)90047-R

Pereira, W. E. \& Hostettler, F. D. (1993). Nonpoint Source Contamination of the Mississippi River and Its Tributaries by Herbicides. Environ. Sci. Technol (Vol. 27). Retrieved from https://pubs.acs.org/sharingguidelines

Quednow, K. \& Püttmann, W. (2009). Temporal concentration changes of DEET, TCEP, terbutryn, and nonylphenols in freshwater streams of Hesse, Germany: Possible influence of mandatory regulations and voluntary environmental agreements. Environmental Science and Pollution Research, 16(6), 630-640. DOI: 10.1007/s11356-009-0169-6

Sandstrom, M. W., Kolpin, D. W., Thurman, E. M. \& Zaugg, S. D. (2005). Widespread detection of N,N-diethyl-m-toluamide in U.S. streams: Comparison with concentrations of pesticides, personal care products, and other organic wastewater compounds. Environmental Toxicology and Chemistry, 24(5), 1029-1034. DOI: 10.1897/04-297R.1 
Sorensen, J. P. R., Lapworth, D. J., Nkhuwa, D. C. W., Stuart, M. E., Gooddy, D. C., Bell, R. A. \& Pedley, S. (2015). Emerging contaminants in urban groundwater sources in Africa. Water Research, 72, 51-63. DOI: 10.1016/j.watres.2014.08.002

Stuart, M., Lapworth, D., Crane, E., \& Hart, A. (2012). Review of risk from potential emerging contaminants in UK groundwater. Science of the Total Environment, 416, 1-21. DOI: 10.1016/j.scitotenv.2011.11.072

Sun, H. Q., Du, Y., Zhang, Z. Y., Jiang, W. J., Guo, Y. M., Lu, X. W., Zhang, Y.M.\& Sun, L. W. (2016). Acute toxicity and ecological risk assessment of benzophenone and N,N-diethyl-3 methylbenzamide in personal care products. International Journal of Environmental Research and Public Health, 13(9). DOI: 10.3390/ijerph13090925

Swale, D. R., Sun, B., Tong, F. \& Bloomquist, J. R. (2014). Neurotoxicity and mode of action of N, Ndiethyl-Meta-toluamide (DEET). PLoS ONE, 9(8).

https://doi.org/10.1371/journal.pone.0103713

TUBITAK MAM. (n.d.). Havza Koruma Eylem Planlar1Seyhan Havzasi. Retrieved from https://www.tarimorman.gov.tr/SYGM/Belgeler/ havza koruma eylem planları/Seyhan_Havzasi.pdf

Weeks, J. A., Guiney, P. D. \& Nikiforovz, A. I. (2012). Assessment of the environmental fate and ecotoxicity of N,N-diethyl-m-toluamide (DEET). Integrated Environmental Assessment and Management, $\quad 8(1), \quad 120-134 . \quad$ DOI: 10.1002/ieam. 1246

Weigel, S., Kuhlmann, J. \& Huhnerfuss, H. (2002). Drugs and personal care products as ubiquitous pollutants: occurrence and distribution of clofibric acid, caffeine and DEET in the North Sea. Science of The Total Environment 295, 131141.

Yang, X., Chen, F., Meng, F., Xie, Y., Chen, H., Young, K., Luo, W., Ye, T., \& Fu, W. (2013). Occurrence and fate of PPCPs and correlations with water quality parameters in urban riverine waters of the Pearl River Delta, South China. Environmental Science and Pollution Research, 20(8), 5864-5875. DOI: 10.1007/s11356-0131641-X

Yoon, Y., Ryu, J., Oh, J., Choi, B.-G. \& Snyder, S. A. (2010). Occurrence of endocrine disrupting compounds, pharmaceuticals, and personal care products in the Han River (Seoul, South Korea). The Science of the Total Environment, 408(3), 636-643. DOI: 10.1016/j.scitotenv.2009.10.049 